\title{
Pietro Porcinai and Pinocchio's Park in Collodi, Italy: Art, Garden, Landscape
}

\author{
Claudia Maria Bucelli \\ New York University, Villa La Pietra - Firenze, Via Benedetto Castelli 36 Firenze FI, Italy
}

Copyright $(\mathrm{C} 2017$ by authors, all rights reserved. Authors agree that this article remains permanently open access under the terms of the Creative Commons Attribution License 4.0 International License

\begin{abstract}
Pinocchio's Park was created within a context of great historical significance, as it is located near one of the most lavish examples of eighteenth century gardens, Villa Garzoni, the ancient fortified dwelling of Collodi. This innovative model of contemporary amusement garden with art also reflects the aesthetics of the traditional Tuscan rural landscape. It is an example of rare artistic, cultural and historical relevance created, "to the measures of infancy", over a twenty-year period in post-war Italy with the aim of boosting the local economy. To this day, it still represents a unique model of landscape-meets-art. From the moment it appeared, Pinocchio's Park succeeded in making real a mental landscape already existing for so many children dreaming about their friend Pinocchio. It brought to life an environmental art form ahead of its time, set in a garden reminiscent of childhood with sculptures, architectural follies and furnishings, which echo the events of a fairytale familiar to millions. It created an "imaginative reality" providing the setting for a meta-language of fun and games based on art and didactics, visually referring to the surrounding landscape.
\end{abstract}

Keywords Historical Landscape, Garden, Art, Pinocchio, Childhood, Pietro Porcinai

\section{Introduction: The Meaning of a Polyhedral Idea}

In 1953 Carlo Anzilotti, the newly-appointed mayor of Pescia (PT), announced a national competition for the creation of a monument dedicated to Pinocchio to celebrate the 70th anniversary of the publication of "The Adventures of Pinocchio" written by Carlo Collodi. The judging committee named Emilio Greco and Venturino Venturi joint winners - the former for his sculpture and the latter for his project of a mosaic square together with architects Renato Baldi and Lionello de Luigi. Architect Marco Zanuso and sculptor Pietro Consagra, came in second place for their park-itinerary, later realized as the addition of the first park in an adjacent area. The decision to award these artists defined both from a conceptual and formal point of view the constitutive features of what were to become Pinocchio's Park. An innovative concept of "urban space", in the guise of a monumental area, both ideally and visually related to a real countryside of farms and villages that in the novel evoke in many readers a recognizable rural Tuscany. A space dedicated to fun and games, a product of the skills and creative sensitivities of different artists using a combination of art, architecture, gardens and landscapes. The Park was designed with the purpose of giving a financial boost to areas affected by the previous war. Therefore, this garden-landscape did not only have an economic-social aim, but also had a moral, aesthetic, educational and recreational objective. In fact, it was strictly connected both to the beauty of its surrounding landscape and to its continuous fruition on behalf of the locals.

Pinocchio's Park wasn't comprised of a mere economic local support, but rather, arranged itself as an unavoidable semantic sustenance to the whole contiguous land. This innovative space-idea realized as a journey into a garden - a landscaped itinerary as an example on ante litteram environmental art [1], evoking the adventures of the famous puppet - was in fact realized all-in-one with the surrounding areas, involving a continuous ideological and visual reference to both the diffuse magnificence of the environment and its historical artistic glories. Also, in the potential of the planetary celebrated novel "that, almost translated in all worldwide idioms, is understood by all the people on earth" [2] an overgrown ample field was intended to be drained. This suburban area, surrounded by fruit trees and olive orchards used as a landfill, was intended for the Park, and therefore destined to be transformed into a garden and transfigured into a living art scene.

As the famous novelist Carlo Lorenzini, who renamed himself 'Carlo Collodi' as homage to his village's name [3], brought his personal visual memory inside the novel's descriptive landscapes universality, likewise visual connections constituted Pinocchio's Park's peculiarity, as several compositive and sight links to the ethic-aesthetic landscaped entity surrounding it. The Park in fact, in echoing 
the novel places and events, articulated "to the measures of infancy", [4] gives birth to spaces, paths, episodes, artifacts, colors, linking itself to the artistic dimension held therein, and, through short perceptive touches to the surrounding landscape scenario.

Already from the very beginning, the first realized space-monument dedicated to Pinocchio - the square mosaic walled piazza also referred to by the American press as the "magic square" - had to be connected through a pedestrian bridge on the Pescia River to Villa Garzoni's baroque style garden. The square itself also had to be surrounded by evergreen hedges, recalling those of both Garzoni and Boboli Garden, constituting a geometrical border linking the human artifact to the surrounding anthropic environment. An eye-level dark green living wall - later evolved into a high tree wooden area of Mediterranean vegetation - had to create a margin connection between the charming mosaic space and the surrounding historical agrarian Tuscan landscape. [7]

\section{Method: A Fairy Tale Brought to Life}

The first nucleus of the park was therefore born as both a visual and physical connection toward Villa Garzoni, the antique fortified dwelling of Collodi. From Pinocchio's square it to the fascinating surrounding Valdinievole landscape is often defined as the garden of Tuscany.

The joint winners' creation was brought to life between 1953 and 1956 starting the first nucleus of the park. The $30 \times 30$ sq. $\mathrm{m}$ square tessellated piazza, delimited by mixti-linear contoured walls (Figure 1) adorned by Venturino Venturi with 22 mosaic scenes recalled events occurring in the fairytale. Nearby was collocated Emilio Greco's artistic work, a bronze statue of Pinocchio who, held by the Fairy, becomes a boy as in an upward movement guided by the Dove. (Figure 2)

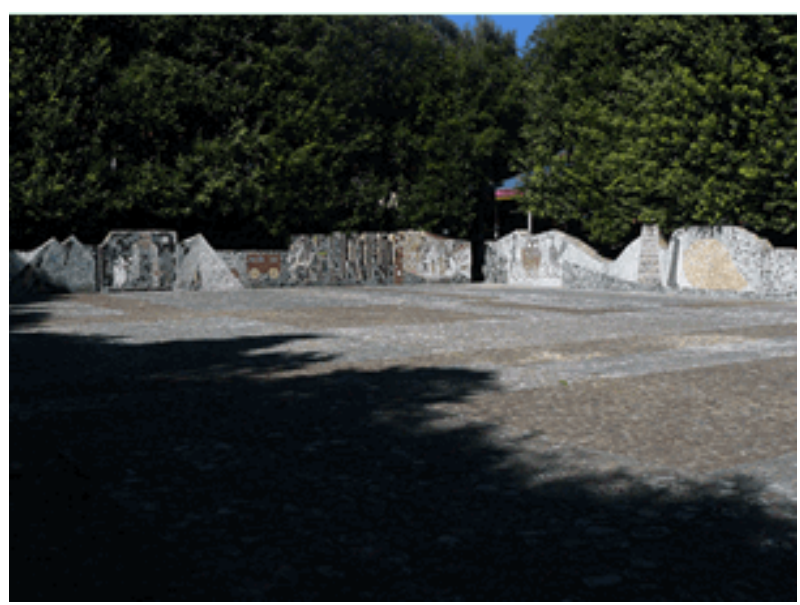

Figure 1. Pinocchio's Park, two of the four walls of the 'Magic Square' decorated with the 22 mosaic scenes by Venturino Venturi recalling events occurring in Pinocchio's fairytale. Photo Claudia Maria Bucelli

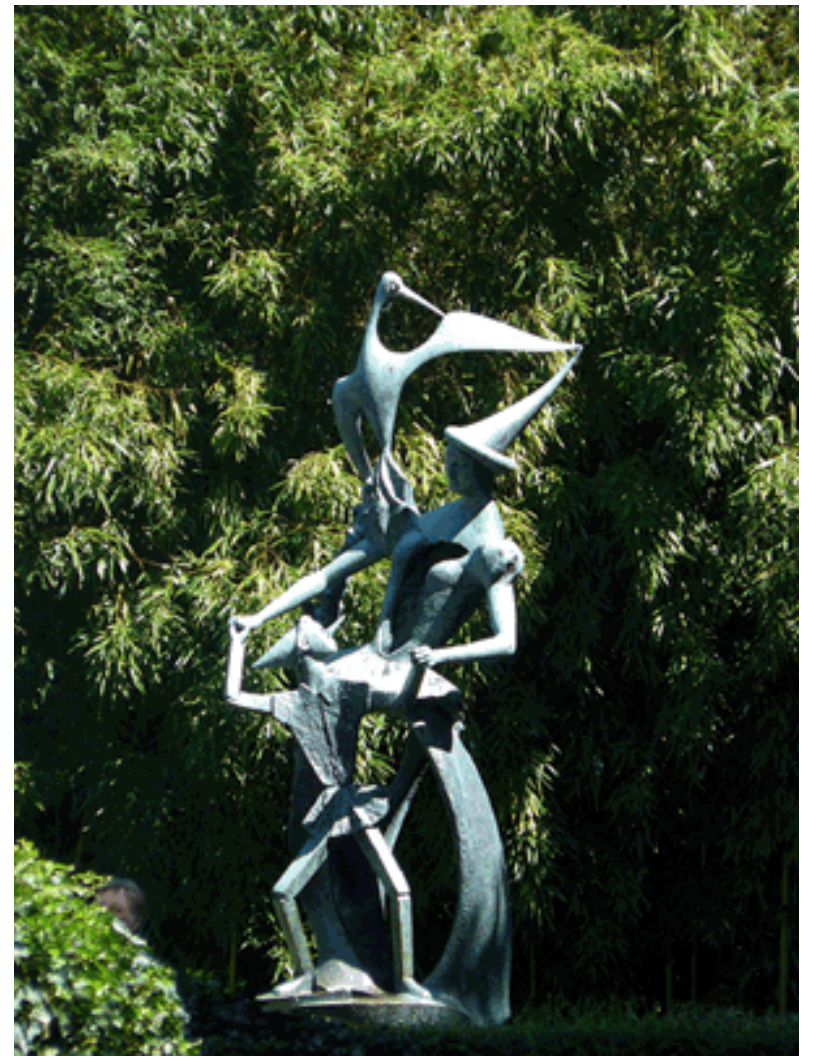

Figure 2. Pinocchio's Park, Emilio Greco's bronze statue of Pinocchio who, held by the Fairy, becomes a boy as in an upward movement guided by the Dove. Photo Claudia Maria Bucelli

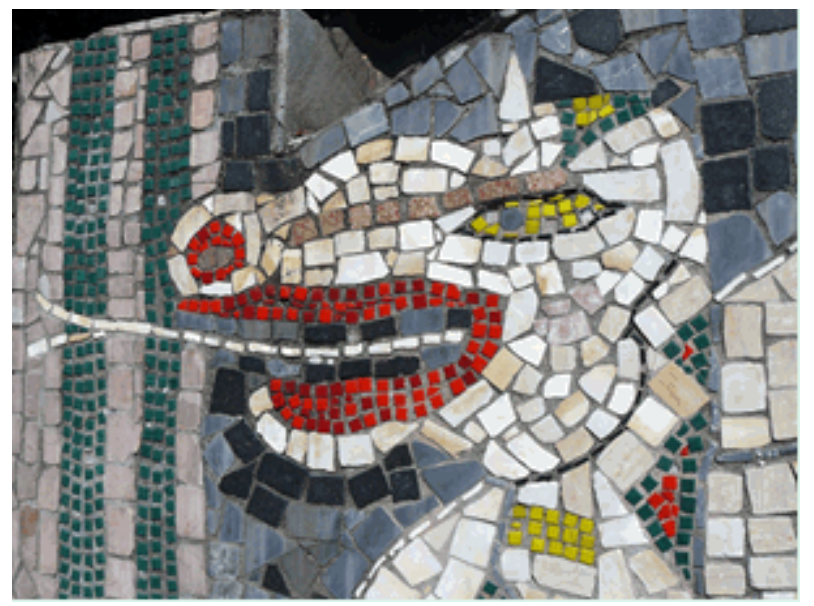

Figure 3. Pinocchio's Park, Venturino Venturi, mosaics decorating the four walls of the 'Magic Square': 'The Snake' who burst from laughing at Pinocchio's expense. Photo Claudia Maria Bucelli

They all recall events that occurred in the fairytale such as the making of Pinocchio by Geppetto, Pinocchio's village, Pinocchio's escape, the puppets of the big puppet theatre with the big puppet's master, the Carabiniere and the prison, the Cat and the Fox and the Golden Coin Tree, the Good Fairy, the Snail Porter, the Snake, the Toy Land, and the Whale. (Figure 3) (Figure 4) (Figure 5) The aim of the first park core was also to stimulate children to move and play into a theatrical space, enclosed all around by stagecraft scenes decorated by fanciful images within an interactive 
interaction with the monument itself. The 'magic square' intended in fact to be both a ludic and a sociality space to be physically explored, climbed, overpassed, crossed and walked down high and low for, from inside and out, glimpsed by the wall holes or investigated around the perimeter. This course is a playful way of reliving in homology to the fairy tale the emotional itinerary of the famous puppet throughout his many adventures.

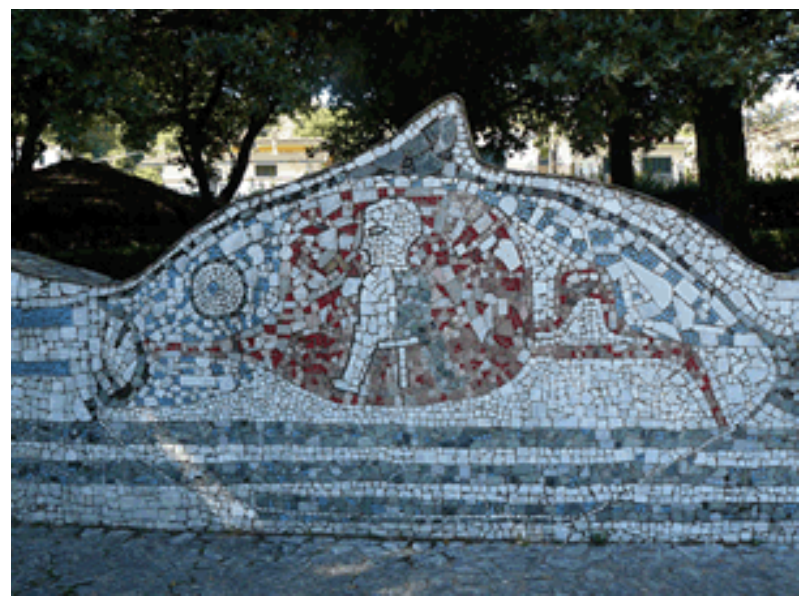

Figure 4. Pinocchio's Park, Venturino Venturi, mosaics decorating the four walls of the 'Magic Square': 'The Whale' with Geppetto inside. Photo Claudia Maria Bucelli

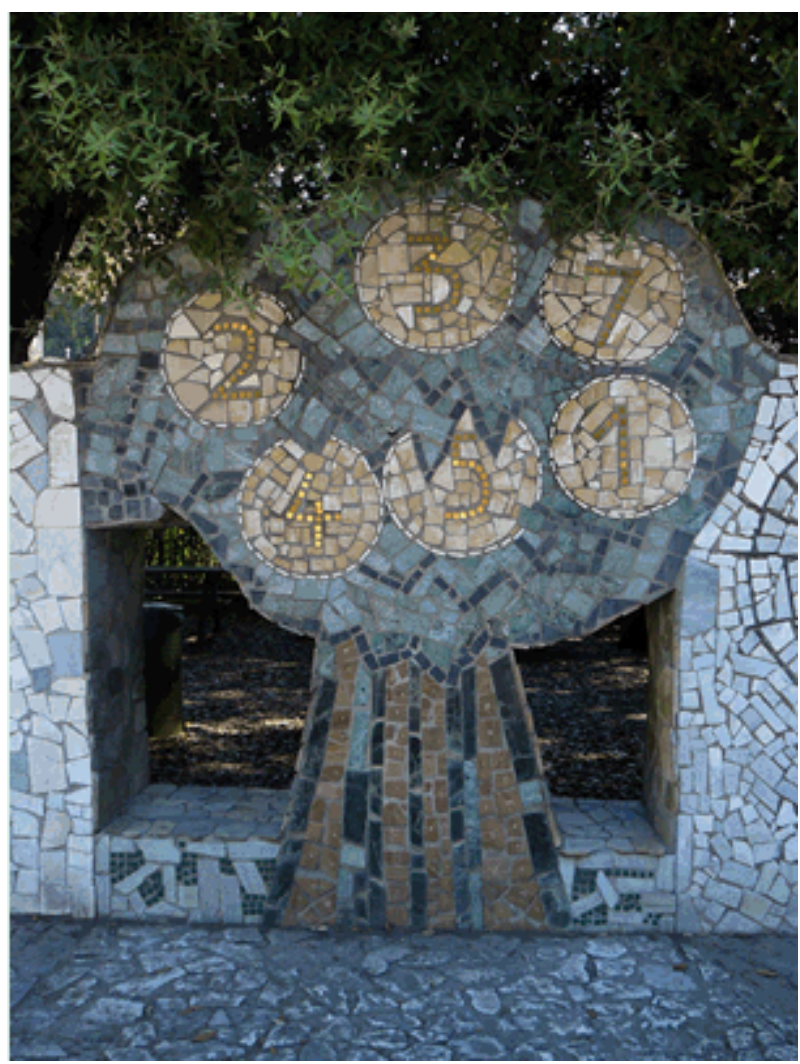

Figure 5. Pinocchio's Park, Venturino Venturi, mosaics decorating the four walls of the 'Magic Square': 'The Golden Coin Tree'. Photo Claudia Maria Bucelli
Subsequently, between 1956 and 1972, the Land of Toys, Zanuso's project, which came second in the competition, was built in the South-East side of the park. Pietro Porcinai was then called in for his substantial landscape contribution to the project. The Land of Toys is a space-itinerary, which maintains a sort of conceptual continuity with the adjacent mosaic square. It was inspired by the magical land described by Collodi in his masterpiece, the place where Pinocchio and Candlewick are taken on a cart driven by 12 pairs of donkeys. It embodies that a dream-like world dedicated exclusively to the activities of those who live in it, children, "the eldest being 14 and the youngest only 8 " [8]. This is a place dedicated to entertainment and located in a mysterious setting, detached from reality. Such location was never formally described by Collodi and was brought to life in Pinocchio's Park thanks to the brilliance of the artists who successfully managed to convey the sentiment - rather than the illustration - of the irreverent, rebellious and playful personality of this famous puppet. Moreover, a place where one can experience moments of magic and play in a little garden-world which even before being built was already in the mental imagery of many children who had read or dreamt about this beloved puppet.

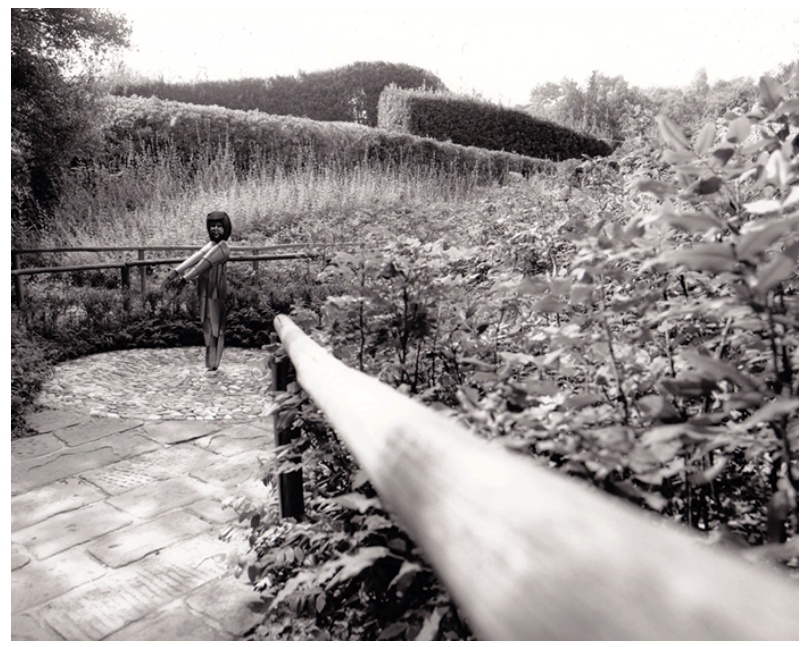

Figure 6. Pinocchio's Park, 'The Fairy Child' surrounded by flowers. Courtesy of Alessandro Sardelli

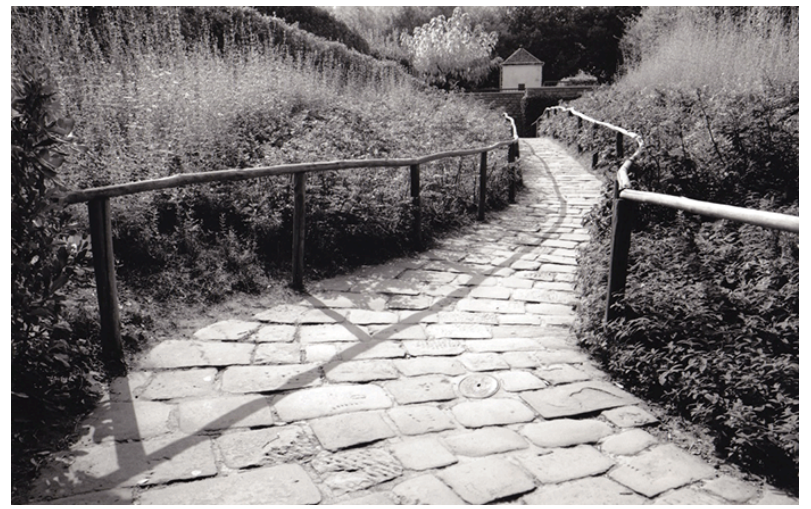

Figure 7. Pinocchio's Park, The Fairy's House, exactly like in the story, appears as white as snow against the dark green backdrop of the vegetation. Courtesy of Alessandro Sardelli 
The trail begins in Pinocchio's Village, the recreation of a Tuscan hamlet. Departing from the village is a sinuous paved trail blocked by the Carabiniere who wants to catch Pinocchio, who is followed by Jimmy Cricket and the Great Marionette Theatre. At the top of the first hill, there is the gazebo of the Red Shrimp Inn and the Fox and the Cat who are waiting to trick the puppet. Thereafter, appears the Wood of the Villains, wherein the Cat and Fox surface once again, and this time hooded, armed and ready to attack Pinocchio. Immediately following, there is a clearing where the Fairy Child, surrounded by flowers, (Figure 6) saves Pinocchio from the two pesky animals. From there on, The Fairy's House exists (Figure 7), whose sides and rooftop are covered with green bottles set against a backdrop of evergreens. Nearby, on a wall covered by ivy there is a big spiral: it is the Snail who opened the door and brought Pinocchio a fake breakfast. As one walks along the trail to the top of the second hill, is the Field of Miracles and the Tree with a Thousand Gold Coins - two dandelion-like structures with fake coins on either side melted onto the profiles of the Cat and the Fox - which stand for the vacuousness of the mirage. Further ahead are the Black Rabbits carrying a coffin, a warning to Pinocchio, who doesn't want to take his medicine. Furthermore, at the very top, with the Collodi landscape acting as a backdrop, appears the smiling Fairy. Immediately after the Fairy, comes the menacingly arched Snake, wallowing in his coils, who bursts from laughing too much. Then come a series of clear references to the coastal landscape mentioned in the short story - the Crab - who is squirting water - and the Fisherman's Net, with the pan on the flame, ready to fry Pinocchio who had been mistaken for a fish (Figure 8). Thereafter, the circus where Pinocchio is turned into a Donkey exists (Figure 10).

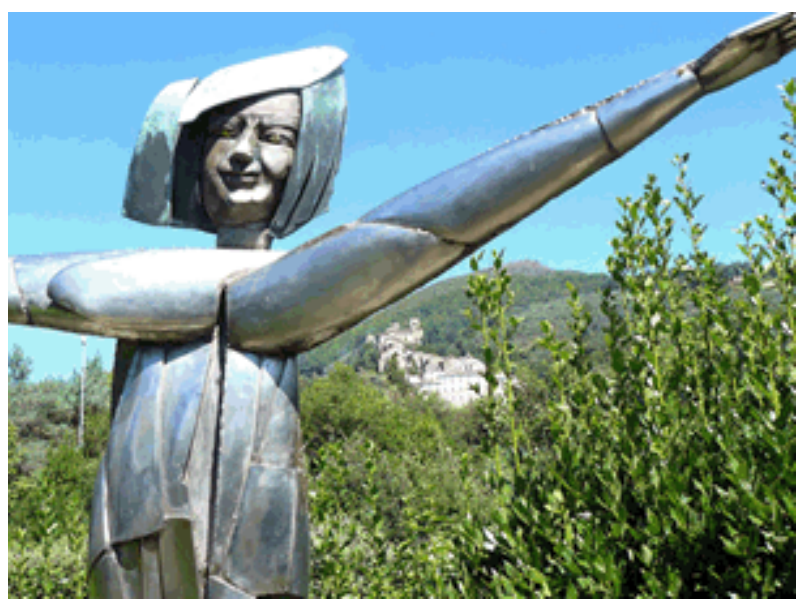

Figure 8. Pinocchio's Park, The Big Fairy smiling at Pinocchio, and the view over Collodi Village behind the statue. Photo Claudia Maria Bucelli

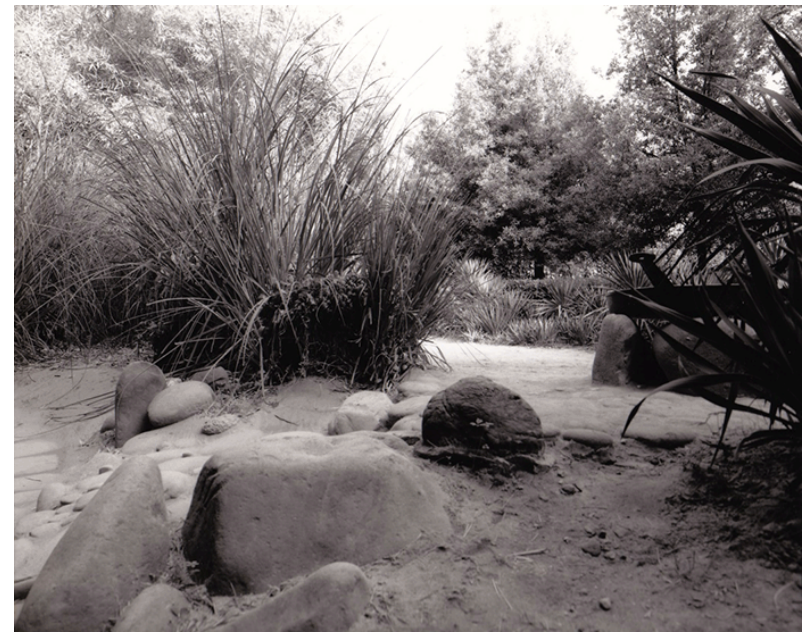

Figure 9. Pinocchio's Park. The maritime and tropical scenery of the second main landscape near the Green Sailor's Pan. Courtesy of Alessandro Sardelli

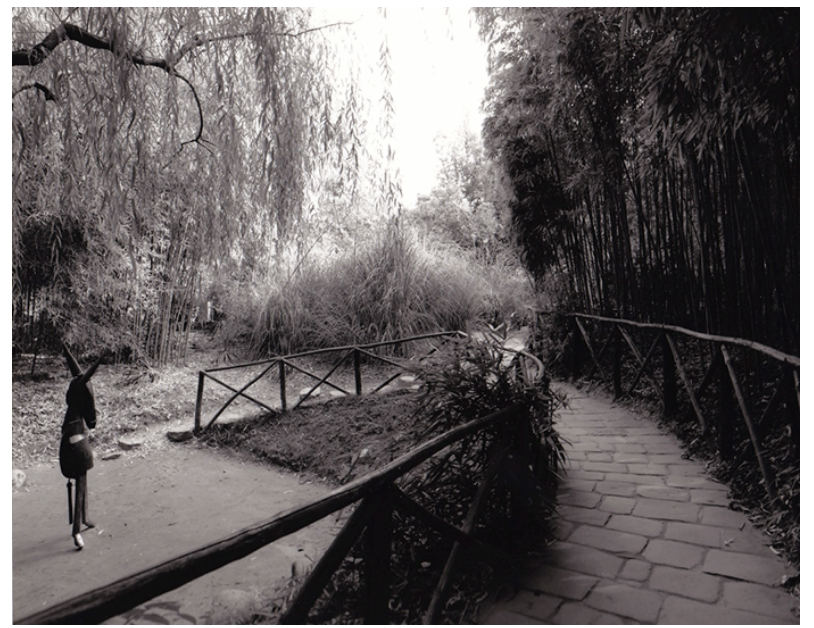

Figure 10. Pinocchio's Park, Pinocchio as a donkey at the Circus. Courtesy of Alessandro Sardelli

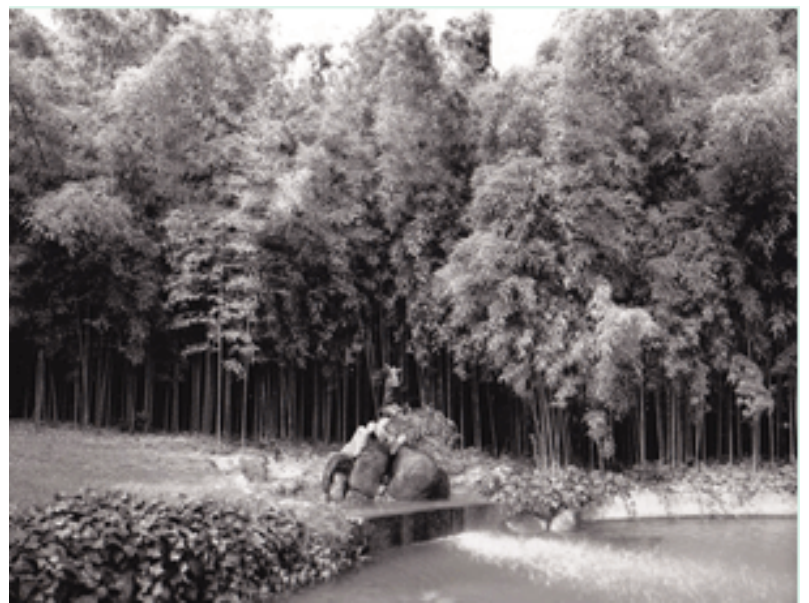

Figure 11. Pinocchio's Park, The little Turquoise Goat on a rock in front of the whale. Courtesy of Alessandro Sardelli

Ahead is the lake with the Big Shark and its immense jaws, an impressive reinforced concrete folly made by Marco Zanuso where Pinocchio later finds his father Geppetto. 
Opposite, on a rock, is The Turquoise Goat who is calling Pinocchio (Figure 11). Finally, the sculpture Pinocchio Waving Goodbye emerges at the end of the trail. Pinocchio has now become a boy (Figure 12), and he is smiling while waving to the visitors who are leaving the fairytale to enter the play area where beneath the Avenue of Holm Oaks, there is the Labyrinth, the Pirate Ship, and the Pirate Cave.

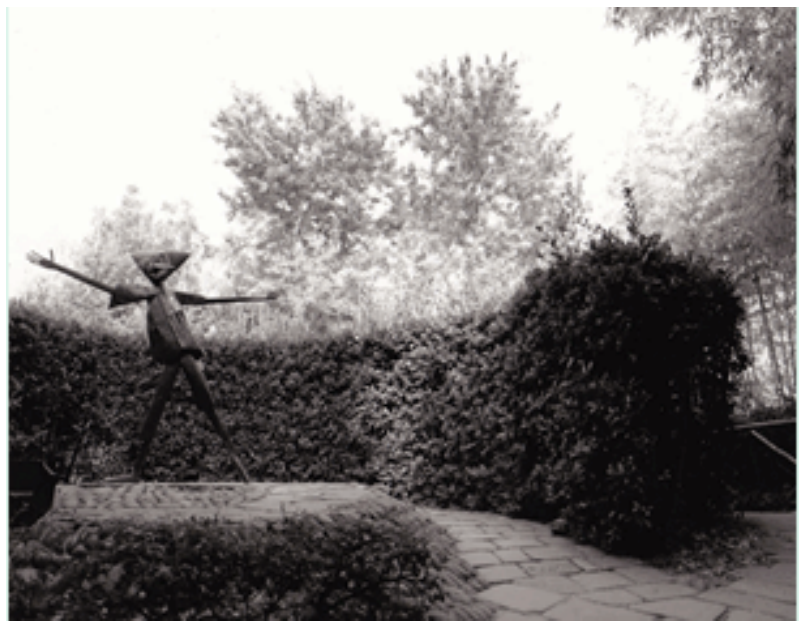

Figure 12. Pinocchio's Park. At the end of the journey, Pinocchio, who has finally become a child, greets and welcomes all the children into the park play area. Courtesy of Alessandro Sardelli

In Pinocchio's Park, the idea has been to create a sequence of episodes to amuse the children, but also allow them to reflect, and therefore, it had to have an educational objective. The children are stimulated to move forward and discover other scenes and areas of the garden while interacting with the three dimensional sculptures and follies.

In the initial project, many of the sculptures had to be able to move, they were together a living theatre based upon the novel's descriptions. These intended interactions consisted of: the Child Fairy clapping her hands, the Carabiniere (policeman) moving his arms, Jimmy the Cricket moving his wings, The Blind Cat moving his eyes (from left to right), the Lame Fox moving the bandaged arm, The Assassins bending to stand and sit, The Snake hissing from his mouth and smoke appearing from his tail, the Crab spraying water, the Donkey Pinocchio moving his tail, the Green Sailor's Pan leaping up and down. Unfortunately, the movements seemed to be too expensive and also dangerous, so they didn't materialize.

The trail also features a succession of three different landscape environments which were created for children set in a green superstructure. The "architectural connective tissue" to recall an expression used by Porcinai, was the greenery vigorously plastic modalities based on pre-modelled movements of earth. Each of the three landscapes is characterized by volumes, botanical densities, luminosity, screenings and different colour schemes. These three environments create a parallel garden dimension reminiscent of a fairy-tale land, detached from reality, yet still connected to the surrounding landscape through multiple visual connections. From the evergreen
Mediterranean vegetation of the Village and the Wood of the Villains, to the prominence of laurel and cheese-wood with rose blossoms in the Child Fairy and the Tree with a Thousand Gold Coins. Finally, varieties of Bambusa and other exotic species such as the Pampas Grass, Yucca and Dwarf Cycas species surrounding the Snake and the Shark.

\section{Discussion: Among Imagery and Ever-changing Reality}

As a matter of fact, Pinocchio's Park manages to create this peculiar children's space while respecting the architectural, artistic and landscape creation of a "different" place, a somewhere which is unlike the ordinary, a "somewhere else" where we can leave our daily landscape behind and experience moments of magic and play in a little garden-world which even before being built was already in the mental imagery of many children who had read or dreamt, and, more important, learnt from the experiences of their beloved puppet.

Therefore, a collective mental image has been transformed into a project based on art and gardens. A place where make-believe is designed around vegetation containing architecture and works of art which appear along hills, descents, narrow passages, squares, openings, tunnels, sinuous paths, linear walkways, fake trails and ramifications. This succession of episodes is positioned along winding paths, thus bringing together events, which are sometimes conceptually distant in the narration. Along the trails, which are both compulsory and arbitrary, some unexpected encounters are connected, justified and valued in a succession of "green rooms". A magical artificial world inhabited by the characters of the fairytale in a series of episodes loosely based on the events of the story. This magic atmosphere was brought to life in a space, which has been plastically modelled on the continuous and daring movements of land and fake garden environments, tailor-made for the little visitors to whom the park is dedicated. A world to be explored, deciphered, touched, crawled up and climbed up along its trail and its variably paved steep hills. Finally, a place is playfully reliving the adventures of our friendly puppet.

This magisterial park's shape and views, completed by Pietro Porcinai, is relied on the surrounding landscape which connects the whole realization not only to the visual emergencies, but also to the many inner landscape dynamics. These irreversible ever changing dynamics are strictly related to man's activities, guiding the landscape transformations. Porcinai himself has been conscious of that from the very beginning of his landscaping activity. He affirmed that 'natural beauty is mostly an 'artificial' beauty, being that the Tuscan landscape esthetic is the stratified product of man's work. Therefore, there's no natural beauty that doesn't also contain humankind marks [9]. In intervening into Pinocchio's Park, Pietro Porcinai has 
therefore been able to interrogate the land's historical evolution through the centuries, consequently succeeding in realizing a new landscape in harmony with the pre-existent. He harmoniously placed a contemporary garden into an historical landscape relating art and nature in a single unity. Inside this unity, each episode encourages the visitor to move to the next due to the kinetic, visual, olfactory, tactile stimuli existing in a succession of scenes which are visually separated, but joined by the itinerary. These scenes, with Pietro Consagra statues, are immersed in greenery and varied botanical species. They are arranged at times - due to the foreseen interactive movements of certain sculptures - as stand-alone little theatres reminiscent of the Renaissance, such as the Medici's Granduke Francesco the $\mathrm{I}^{\text {st }} \mathrm{s}$ Pratolino, the famous $\mathrm{XV}^{\text {th }}$ Century garden and its celebrated automata.

\section{Conclusions: Connection VS Abstraction}

Pinocchio's Park was created as an amusement park, but envisioned as so much more. Created nearly in parallel with the American amusement parks, this famous Italian park is in some parts similar, but also characterized by a deeper semantic density and a cultural, social, artistic, economic and ethical implications, far greater than the mere ludic dimension.

Disneyland, the most famous amusement park, projects in fact its visitors into the magical density of unreal spaces, atmospheres and characters directly deriving from Walt Disney's movies. People are thrown into a magic universe basically detached from everyday life, a separate reality allowing both total disconnection and contemporary adhesion to fantasy and illusions. Pinocchio's Park differently interacts with the visitors, as it contains both real and illusion spaces, being made of real and evocated objects. These objects and places create a journey between reality and tale in a variety of situations and attractions, but don't confuse the visitor from reality of the context. In fact, every situation is connected to different parts of the environment and visual references to the contiguous landscape, so that every fantasy flight consequently relates to the historical beauty of the landscape and its stratified memories. This is exalted by Porcinai through perception and boundary transcendence, therefore offering beautiful views to contemplation from several corners of the Park.

As Porcinai clearly wrote, "per proteggere il paesaggio dalla bruttezza occorre educare gli uomini, tutti gli uomini, alla bellezza" [10] (to protect the landscape from unattractiveness, it is necessary to educate man, all men, in beauty.) and together "dirigere gli occhi e il cuore alla stessa mèta: l'ordine nel paesaggio" [11] (To direct your eyes and heart to the same goal: harmony in the landscape.). Therefore, to contemplate the environmental beauty subsequently implies comprehension, defense and conservation, and through Pinocchio Park, this message orienting to the environment protection, is still active and present.

\section{REFERENCES}

[1] Sentieri nell'arte. Il contemporaneo nel paesaggio toscano, a cura di A. Mazzanti, Firenze, Maschietto, 2004, p. 88.

[2] J. Cope, The Beauty of Pinocchio. The Poetics of Place, a cura di I. Marchegiani Jones, T. Haeussler, Firenze, Olschki, 2001, p. 188.

[3] J. Cope, The Beauty of Pinocchio. The Poetics of Place, a cura di I. Marchegiani Jones, T. Haeussler, Firenze, Olschki, 2001, p. 189.

[4] J. Cope, The Beauty of Pinocchio. The Poetics of Place, a cura di I. Marchegiani Jones, T. Haeussler, Firenze, Olschki, 2001, p. 189.

[5] Carlo Lorenzini named himself with the pseudonym of 'Carlo Collodi' after Collodi Village, where his mother was born and where he used to spend his summer holidays every year.

[6] "Pinocchio is quintessentially Tuscan. [...] Pinocchio always finds Tuscany, and never leaves Tuscany. [...] A Tuscany sui generis [...] but Tuscany nonetheless". Cfr. J. COPE, The Beauty of Pinocchio. The Poetics of Place, a cura di I. Marchegiani Jones, T. Haeussler, Firenze, Olschki, 2001, p. 187.

[7] The evergreen edges were intended to remain under the $2 \mathrm{mt}$. height to allow visual connection to the surrounding, but the chosen plants grown much higher during the years, soon becoming now a Mediterranean wood all around the square. Personal interview of Architect Renato Baldi given to the Author, Florence May the 5th 2015.

[8] C. Collodi. Le avventure di Pinocchio, Polistampa, Firenze, 1996, p. 160.

[9] P. Porcinai. Per la bellezza naturale, in "Il Mondo", Firenze, March the 2nd 1946; P. Porcinai. Giardini, Illustrazione, February 1938.

[10] P. Porcinai, Per la bellezza...cit., Il Mondo, Firenze, March the 2nd 1946. Ibidem.

[11] C. M. Bucelli. Committenza privata e pubblica: i giardini di villa e il parco di Pinocchio, Pietro Porcinai a Pistoia e in Valdinievole edited by C. M. Bucelli and C. Massi, Olschki, Firenze, 2012.

[12] C. M. Bucelli, 'Il Parco di Pinocchio a Collodi: lo spazio del giardino e la dimensione del paesaggio' Bollettino dell'Accademia degli Euteleti” Vol. 80, 579-593. 2013.

[13] F. Cambi. Collodi, De Amicis, Rodari. Tre immagini d'infanzia, Edizioni Dedalo, Bari, 1985.

[14] O. Casazza, M. Moretti. Pinocchio a Collodi 50. Mezzo secolo d'arte contemporanea, Nidiaci Grafiche, San Gimignano, 2003.

[15] C. Collodi. Le avventure di Pinocchio, Polistampa, Firenze, 1996.

[16] J. Cope. The Beauty of Pinocchio. The Poetics of Place, edited by I. Marchegiani Jones, T. Haeussler, Olschki, Firenze, 2001. 
[17] P. Porcinai, Per la bellezza naturale, Il Mondo, Firenze, March the 2nd 1946

[18] P. Porcinai, Giardini, Illustrazione, February 1938.
[19] M. Venturi Ferriolo. Etiche del paesaggio. Il progetto del mondo umano, Milano, Editori Riuniti, 2002 